$\overline{\text { Editorial Comment }}$

\title{
小児期の異所性心房頻拍(心耳起源を中心に)
}

\author{
坂口 平馬 \\ 国立循環器病研究センター小览循環器科
}

\section{Focal Atrial Tachycardia During Childhood}

\author{
Heima Sakaguchi
}

Department of Pediatric Cardiology, National Cerebral and Cardiovascular Center, Osaka, Japan

今月号の本誌に武智らの論文 ${ }^{1)}$ が掲載されている. 基礎心疾患を伴わない異所性心房頻拍の臨床的特徵からその治 療指針を提案する論旨である。まずは，その発症時期により2つに大別することができる，胎児期，新生児期発症の 異所性心房頻拍例では, 自然消退が期待でき, 薬物治療で成長を待つことが望ましい. 学童期発症例や, 学童期まで に自然消退しなかった症例に対しては, 高周波カテーテルアブレーションが安全に頻拍を治療できることが述べら れている，学童期以降に頻拍が残存または発症した症例において，臨床的に最も問題となることは頻拍誘発性心筋 症の発症であろう.

本稿では, 小児期の異所性心房頻拍の臨床的特徵をまとめ, 特に小児期に多く発症する心耳起源心房頻拍につい て解説し, 頻拍誘発性心筋症の予防に寄与すると思われる学校心電図検診の心電図判読に生かしていただきたい.

\section{乳幼児期発症の異所性心房頻拍}

小児期の異所性心房頻拍は発症時期で分けると, 武智らの述べるように胎児・新生児期もしくは学童期と考えら れる. Salerno らの報告2)では, 3 歳未満の異所性心房頻拍例は平均 12 力月間の薬物治療の後, $78 \%$ の症例で完全に 自然消退している，われわれの施設では，これに準じて1歳まで薬物治療を継続，ここで内服を中止して自然消退の 有無を確認して頻拍の残存があれば, 3 歳まで薬物治療を継続している. 再度内服中止をトライし, やはり残存する ようなら高周波カテーテルアブレーションを考慮する方針をとっている.

\section{学童期発症の異所性心房頻拍}

成人の異所性心房頻拍の起源としては肺静脈, 冠静脈洞や房室弁輪といった異常自動能の獲得が多い sinus venosus 由来の心房組織が多いことが知られている. 心耳は embryonic atria 由来ではあるが, Blom らの報告では刺激伝導系 細胞の発生で特異的に発現する HNK-1 を胎児心で観察すると, 心耳にも一時的に HNK-1 が発現していることが示 され, 心耳が異常自動能を獲得する可能性が十分にあることが推察されている3 ${ }^{3}$. 成人に㧍ける心耳起源の心房頻拍 の報告は多くが若年者であること, 男性に多いことがいくつもの報告で述べられている。一方で武智らの報告にあ るように, 小児期の心房頻拍の起源としては心耳が多いと報告さされている4 7)。つまり，心耳起源の心房頻拍は男 性に多く，その発症時期が早いことが伺える。

\section{心耳起源心房頻拍}

心耳起源の心房頻拍の特徵は incessant form をとることが多く ${ }^{8)}$, 洞調律よりやや速い心拍数で持続する症例が多 いため自覚症状にそしく，この特徴が診断の遅れにつながっているものと思われる. 武智らの報告にあるように, 心 耳起源以外の心房頻拍では発作性に頻拍が出現することが多く, 頻拍に伴う臨床症状が診断の契機となる.さらに この特徵のため長期間比較的頻脈が持続し, 頻拍誘発性心筋症を併発すると考えられる. わが国では, その診断は学 
校心電図検診が契機となることが多くその心電図上の特徵の認識が重要となる. P 波の形態は右心耳起源の場合は V1，V2で特徵的な QS パターンを示す。これはちょうど右側胸部誘導の単極電極が右心耳の真下に存在することに 起因する，また左心耳の場合は I, aVL 誘導できれいな陰性 P 波を示す. 左房起源の異所性調律でこの特徽を有する のは左心耳㧍よび僧帽弁輪側壁がほとんどである. 前述のように心耳起源心房頻拍は安静時には比較的頻脈で, 運 動に伴い accelerate する特徵を有するため, 学校心電図検診の判読においては, 心拍数のみならず P 波の形態に注意 を払う必要があると考えられる。

また Holter 心電図所見としては, 心房頻拍の一時的な停止後に sinus pause がみられること, 安静時の頻拍中に II 度房室ブロックがみられることが特徵とされる ${ }^{8)}$. しかし，この頻拍停止時の sinus pause や安静時の頻拍中にみられ る房室ブロックは頻拍の治療後には全くみられなくなり, overdrive suppression に伴う機能的なものと判断される. そのため, これらの現象はカテーテルアブレーションの contra-indication とはならないといえる.

\section{心耳起源心房頻拍のカテーテルアブレーション}

心耳起源の心房頻拍では，その多くは心耳基部に焦点が存在することがわかっている5,9). 小児期の心房頻拍のア ブレーション治療においては麻酔が必須となることが多く, 手技中に頻拍が出現するかどうかが重要なポイントと なる.しかし, 心耳起源の頻拍の場合は経験上, 頻拍は間欠的に出現し, 苦労することはあまり多くない. しかし, 心耳の解剖学的構造上, 櫛状筋のヒダに阻まれ通電中に頻拍は消失するが, 通電後すぐに再燃することや, 心外膜側 に起源があり，同様に頻拍を停止させられないことを経験する．近年は open irrigation catheter が使用できるようにな り, 血流の少ない心耳内での通電が有効かつ安全に行われるようになった。しかし, 頻拍誘発性心筋症を併発してい る症例では, カテーテルアブレーション不応例に拈いては外科的に心耳切除を考慮する必要がある. この場合は, 心 耳内の焦点の位置を十分に把握する必要がある. 前述のように, 心耳内の起源は心耳基部に存在することが多いか らである。また，まれに心耳瘤が頻拍の原因であることも報告され，これもカテーテルアブレーション不応例が多く 外科的心耳切除の適応となることがある. よってカテーテルアブレーションを行う際には必ず心耳造影を行うべき と考える.

\section{カテーテルアブレーションの適応}

心耳起源心房頻拍に対するカテーテルアブレーションの有効性と安全性はこれまでにも多くの報告がなされてお り, 十分な知識と経験があれば積極的に行うべきであると考える.心耳起源の心房頻拍においては, その臨床特徵か ら頻拍誘発性心筋症を併発しやすく, われわれの経験では半数の症例で併発している ${ }^{8)}$. よって, その安全性, 有効 性から十分な体格があり心耳起源心房頻拍と判断されれば, 家族に informed consent を行ったうえでカテーテルアブ レーションの適応と考える。

\section{おわりに}

心耳起源の心房頻拍を中心に小児期心房頻拍の臨床的特徵を述べた。っとも強調したい点は, 心耳起源異所性 心房頻拍ではその特有の特徵から, 小児期に発症しやすく, 自覚症状にそしいことである. ゆえに, 頻拍誘発性心筋 症を併発しやすいと考えられる。わが国では幸いにして学校心電図検診があり，これを契機に診断されることを多 く経験する. その心電図学的特徵をわれわれが広く認識することが頻拍誘発性心筋症を予防する, もしくは早期発 見し治療につなげることとなると信じている. 


\section{【参考文献】}

1) 武智史恵, 森島宏子, 立野 滋, ほか：基礎心疾患のない小児期異所性心房頻拍の検討. 日小児循環器会誌 2014；30：651-658

2) Salerno JC, Kertesz NJ, Friedman RA, et al: Clinical course of atrial ectopic tachycardia is age-dependent: result and treatment in children $<3$ or $>3$ or $=3$ years of age. J Am Coll Cardiol 2004; 43: 438-444

3) Blom NA, Gittenberger-de Groot AC, DeRuiter MC, et al: Development of the cardiac conduction tissue in human embryos using HNK-1 antigen expression: possible relevance for understanding of abnormal atrial automaticity. Circulation 1999; 99: 800-806

4) Freixa $X$, Berruezo A, Mont L, et al: Characterization of focal right atrial appendage tachycardia. Europace 2008; 10: 105-109

5) Roberts-Thomason KC, Kistler PM, Haqqani HM, et al: Focal atrial tachycardias arising from the right atrial appendage: electrocardiographic and electrophysiologic characteristics and radiofrequency ablation. J Cardiovasc Electrophysiol 2007; 18: 367372

6) Yamada T, Murakami Y, Yoshida Y, et al: Electrophysiologic and electrocardiographic characteristics and radiofrequency catheter ablation of focal atrial tachycardia originating from the left atrial appendage. Heart Rhythm 2007; 4: 1284-1291

7) Wang YL, Li XB, Quan X, et al: Focal atrial tachycardia originating from the left atrial appendage: electrocardiographic and electrophysiologic characterization and long-term outcomes of radiofrequency ablation. J Cardiovasc Electrophysiol 2007; 18: 459464

8) Sakaguchi H, Miyazaki A, Yamamoto M, et al: Clinical characteristics of focal atrial tachycardias arising from the atrial appendages during childhood. Pacing Clin Electrophysiol 2011; 34: 177-184

9) Hillock RJ, Singarayar S, Kalman JM, et al: Tale of two tails: the tip of the atrial appendages is an unusual site for focal atrial tachycardia. Heart Rhythm 2006； 3: 467-469 